\title{
DIMENSI KEKUASAAN PENGHULU ADAT MELAYU RIAU DALAM PELAKSANAAN DEMOKRASI LOKAL
}

\author{
Asrinaldi $^{1}{ }^{2}$, Azwar $^{3}$

\begin{abstract}
The Malay penghulu adat have traditional authority that can direct their people to maintain their own identity and existence. However, in fact the function of these Malay penghulu adat is only in the context of customs and culture, but in some cases these penghulu also influence the implementation of local democracy. For example, in the election process of the head of the region, although the function of the penghulu adat as a leader can direct the tribe and his people, but they are rarely used because it is contrary to the principle of propriety in Malay custom. This article is derived from field research using descriptive qualitative methods. The research informant was chosen using purposive sampling technique to get the required data. They are penghulu adat, local elections commissions, bureaucrats, politicians and local academics. This article finds the dimensions of the Malay penghulu adat authority only used to establish Malay identity by strengthening Malay customs and culture. Moreover, the people of Riau are more complex than the social and cultural aspects. The findings of the study found that the dimensions of penghulu adat of Riau Malay tend to be used to establish Malay identity by strengthening their customs and culture. The involvement of the Riau Malay community providing support in the elections is oriented only on how Malay culture can be maintained and used by regional heads in administering government. In other words, the Malay people want their culture to be preserved through local government policy and not to be used for political activities. It is therefore not surprising that every Riau governor elected was awarded the Datuk Seri Setia Amanah. This aims for the governor to preserve the culture of Riau Malay.
\end{abstract}

Keywords: Power, Politics, Penghulu, ethnic and Malay.

\section{Abstrak}

Penghulu adat Melayu Riau memiliki otoritas tradisional yang dapat mengarahkan masyarakatnya untuk menjaga identitas dan eksistensi adatnya. Faktanya, walaupun fungsi penghulu adat Melayu ini hanya dalam konteks adat dan budaya, namun dalam beberapa kasus penghulu ini turut mempengaruhi pelaksanaan demokrasi lokal. Misalnya, dalam proses pemilihan kepala daerah, fungsi penghulu adat sebagai pemimpin dapat mengarahkan suku dan kaumnya, namun fungsi ini jarang digunakan karena bertentangan dengan kepatutan dalam adat melayu. Artikel ini berasal dari penelitian lapangan dengan menggunakan metode kualitatif deskriptif. Informan penelitian dipilih menggunakan teknik purposif sampling untuk mendapatkan data yang dibutuhkan. Mereka terdiri dari penghulu adat, anggota komisi pemilihan umum

\footnotetext{
${ }^{1}$ Dosen Jurusan IImu Politik, FISIP, Universitas Andalas, Padang.

${ }^{2}$ Korespondensi Penulis, Email: asrinaldi4@gmail.com.

${ }^{3}$ Dosen Jurusan Sosiologi, FISIP, Universitas Andalas, Padang

DOI: 10.25077/jantro.v20.n1.p57-69.2018

JANTRO ISSN: 2355-5963 (Online)

under Lisensi Creative Commons Atribusi-BerbagiSerupa 4.0 Internasional
} 
daerah, birokrat, politisi dan akademisi setempat. Hasil penelitian menemukan dimensi kekuasaan penghulu adat Melayu Riau cenderung digunakan untuk membangun identitas Melayu dengan penguatan adat dan budaya mereka. Keterlibatan masyarakat Melayu Riau memberikan dukungan dalam Pilkada hanya berorientasi pada bagaimana budaya Melayu dapat dipertahankan dan digunakan oleh kepala daerah dalam menyelenggarakan pemerintahan. Dengan kata lain, masyarakat Melayu menginginkan kebudayaan mereka dilestarikan melalui kebijakan pemerintah daerah dan bukan dimanfaatkan untuk politik praktis. Karenanya tidak mengherankan setiap gubernur Riau terpilih dianugerahkan gelar adat Datuk Seri Setia Amanah. Ini bertujuan agar gubernur ikut melestarikan kebudayaan Melayu Riau tersebut.

Kata Kunci: Kekuasaan, Politik, Penghulu, dan Melayu

\section{A. PENDAHULUAN}

$\mathrm{K}$ emajemukan Indonesia turut mempengaruhi bagaimana demokrasi di tingkat lokal dilaksanakan. Demokrasi lokal, dalam beberapa hal, dapat ditelusuri dari nilai-nilai sosial dan budaya yang diamalkan masyarakat setempat dalam sistem pemerintahan yang diselenggara kannya (Asrinaldi, 2017:49-51). Tercatat ada sekitar 300 etnis yang hidup di Indonesia dengan berbagai macam kebudayaannya yang tentunya ini mempengaruhi praktik demokrasi di Indonesia. Karena fondasi demokrasi secara nasional dibangun dari nilai-nilai masyarakat dengan berbagai sistem sosial budayanya. Lebih jauh sistem sosial budaya yang dipraktikkan oleh suatu etnis ini akan melahirkan peradaban yang dapat dipelajari keunggulan dan keunikan nya. Misalnya, etnis Melayu Riau yang dikenal pada masa abad pertengahan dan pernah menjadi pusat kerajaan Melayu di nusantara. Dalam abad modern pun kejaya an etnis Melayu ini masih bisa ditelusuri dari kebudayaan dan simbol-simbolnya di Provinsi Riau.

Menariknya bertahannya nilai-nilai adat Melayu ini karena adanya fungsi penghulu dan kelembagaannya untuk melestarikan nilai-nilai tersebut. Penghulu adat diberi legitimasi oleh komunitasnya untuk menjaga dan melestarikan sistem nilai budaya Melayu. Bahkan dalam perkembangannya, kekuasaan penghulu adat Melayu ini dihimpun ke dalam organisasi formal yang dikenal dengan Lembaga Adat Melayu (LAM) di tingkat provinsi dan kabupaten/ kota. Misalnya, LAM Riau tempat berhimpunnya penghulu adat dan tokoh lainnya yang juga memiliki kepedulian dengan tumbuh dan berkembangnya adat dan budaya Melayu Riau. Karenanya tidak mengherankan hampir di setiap daerah Riau memiliki penghulu adat yang berfungsi selain menjaga sistem nilai sosial dan budaya masyarakatnya, juga membimbing anak dan kemenakan dalam komunitasnya. Dengan legitimasi kultural yang dimiliki ini, maka kedudukan penghulu adat melayu Riau menjadi strategis dalam praktik demokrasi di tingkat lokal.

Dalam aspek lain, penghulu adat dalam masyarakat Melayu Riau juga menjadi pemimpin dan mengambil tindakan bagi para pelanggar adat (John Haba, 2011:16). Begitu tingginya kedudukan penghulu adat dalam masyarakat Melayu Riau ini tentu akan mempengaruhi aktifitas politik dan pemerintahan masyarakatnya. Apalagi se jak dilaksanakan Pilkada dengan melibatkan masyarakat sebagai pemilih, maka otoritas tradisional seperti penghulu adat ini semakin mendapatkan tempat dalam komunitas. Karena tidak semua masyarakat di daerah yang memahami proses politik, terutama dalam memilih pemimpin mereka. Tidak jarang kehadiran tokoh informal sebagai tempat bertanya menjadi penting bagi masyarakat. $\mathrm{Di}$ sinilah Penghulu adat Melayu ini memainkan perannya sebagai pemimpin bagi masyarakat lokal. Otoritas

DOI: 10.25077/jantro.v20.n1.p57-69.2018

JANTRO ISSN: 2355-5963 (Online)

under Lisensi Creative Commons Atribusi-BerbagiSerupa 4.0 Internasional 
tradisional penghulu adat Melayu tidak hanya dalam konteks budaya saja. Mereka juga memiliki pengaruh politik dan kekuasaan walaupun dalam derajat yang berbeda-beda.

Politik kekuasaan para penghulu ini terkait dengan otoritas kekuasaan yang mereka miliki karena mendapat legitimasi secara adat. Yang menarik, walaupun penghulu memiliki legitimasi secara adat, namun kekuasaannya mengalami perluasan yang tidak hanya sebatas di bidang adat saja. Dalam filosofi adat Melayu, penghulu tersebut juga bertindak sebagai pemimpin atas anak dan kemenakannya. Secara implisit kekuasaan ke atas anak dan kemenakan ini menggambarkan adanya posisi memerintah penghulu dalam komunitasnya. Karenanya sebagai pemim pin dalam masyarakat Melayu Riau dikenal pemimpin adat dengan gelar datuk Adat, Penghulu Adat, Batin, Ketiapan (Tongkat, Monti, Majokayo, Majolelao), Bintara, Penghulu Balai, dan Penghulu Istana. Pucuk dari jabatan adat ini adalah Raja yang dikenal juga dengan "Pucuk Jala Pumpunan Ikan" atau "teraju negeri" (Effendy, 2013:167).

Karenanya tidak mengherankan, dalam kehidupan masyarakat Melayu Riau yang sangat kental dengan adat dan budayanya sehingga kedudukan penghulu adat ini sangat diperhitungkan oleh elite politik dan pemerintahan di daerah ini. Apalagi daerah ini memiliki kedekatan dengan adat dan budaya Minangkabau. Misalnya, adat dan budaya Melayu di Kabupaten Kampar dan Kabupaten Kuantan Singingi di Provinsi Riau memiliki corak yang hampir sama dengan adat dan budaya Minangkabau (Hamidy, 1993). Tentunya, kebiasaan adat dan budaya ini turut mempengaruhi aktifitas penghulu adat di daerah tersebut, terutama dalam kehidupan masyarakatnya.

Lucyan W. Pye dalam bukunya Asian Power and Politics: The Cultural Dimension of Authority (1985) menjelaskan adanya fenomena kekuasaan informal yang dimiliki oleh pemimpin di luar pemerintahan menggambarkan adanya dominasi budaya dalam kepemimpinan tersebut. Dan tidak jarang kekuasaan tradisional ini juga harus berhadapan dengan kekuasaan formal dari pemerintah. Lebih jauh, Pye melihat unsur budaya menjadi hal yang tidak terpisahkan dalam memahami kekuasaan yang dimiliki oleh pemimpin di luar pemerintahan sehingga menjadi perhatian karena mempe ngaruhi proses pembangunan politik di sebuah negara. Katanya "Political power is extraordinarily sensitive to cultural nuances, and that, therefore, cultural variations are decisive in determining the course of political development (1985:vii)."

Dengan melihat aktifitas penghulu adat Melayu Riau tersebut, maka dapat ditelusuri fungsi kepenghuluannya dalam kehidupan masyarakatnya. Pertama, penghulu adat Melayu memiliki fungsi menjaga dan melestarikan nilai, norma dan keyakinan yang terdapat dalam adat Melayu Riau. Fungsi utama ini menjadi perhatian karena semakin kuatnya nilai-nilai global masuk ke dalam kehidupan anak dan kemenakannya. Menjaga dan melestarikan nilai-nilai kemela yuan ini juga terkait dengan menjaga marwah bangsa Melayu yang berubah sesuai dengan perkembangan zaman. Bahkan adat dan budaya Melayu di daerah Riau sendiri juga sudah mengalami asimilasi dengan nilai-nilai budaya sukubangsa lain yang juga semakin berkembang di tanah Melayu. Sifat budaya Melayu yang terbuka menjadi salah satu penyebab mengapa nilai-nilai Kemelayuan ini semakin tergerus oleh perkembangan zaman. Karena tidak mengherankan, keberadaan penghulu adat Melayu ini yang terus menggali dan menyegarkan kembali pemahaman anak dan kemenakan di dalam kaum dan sukunya.

Kedua, penghulu adat Melayu juga memiliki fungsi menjaga harta pusaka suku dan kaum, terutama yang berada di wilayah Riau daratan seperti Kabupaten Kampar, Sebagian Kabupaten Pelalawan, Kabupaten Kuantan Singingi dan Sebagian Kabupaten Rokan Hulu. Tidak jauh berbeda dengan etnis Minangkabau yang menjadikan harta pusaka ini sebagai identitas dan kedaulatan kaum dan suku yang dipimpin oleh penghulu adat Melayu ini. Bahkan agar penghulu adat Melayu ini semakin berwibawa di hadapan anak dan kemenakannya, maka hasil dari pemanfaatan harta pusaka ini seperti tanah ulayat, hutan ulayat dan

DOI: $10.25077 /$ jantro.v20.n1.p57-69.2018

JANTRO ISSN: 2355-5963 (Online)

under Lisensi Creative Commons Atribusi-BerbagiSerupa 4.0 Internasional 
sebagainya dimanfaatkan untuk kepenti ngan keluarga besar kaum dan suku. Dengan cara ini, maka legitimasi penghulu adat akan semakin kuat dalam kaum dan sukunya, terutama dalam melestarikan adat dan budaya (Marnelly, 2017:151). Sebalik nya, jika harta kaum dan suku sudah tidak ada, biasanya kedudukan penghulu adat Melayu sudah tidak lagi menjadi tempat mengadu anak dan kemenakannya. Otomatis penghulu adat Melayu kehilangan salah satu fungsinya yang terkait langsung dengan legitimasi dalam komunitasnya. Bisanya kedudukan penghulu adat Melayu yang memiliki akses langsung terhadap pengelolaan harta pusaka kaum dan suku ini membentuk relasi patron-klien dalam komunitasnya.

Ketiga, penghulu adat Melayu juga menjadi tempat menyelesaikan masalah secara bersama-sama dengan kaum dan sukunya. Dengan demikian, melalui peng hulu adat ini akan terwujud perpaduan, persatuan dan kesatuan dalam kehidupan kaum dan sukunya. Biasanya di antara penghulu adat dengan kaum dan sukunya terjadi kedekatan emosional dan psikologis sehingga tidak jarang pula budaya politik yang terbentuk adalah budaya politik subjektif. Seperti yang dijelaskan Gaffar (1999:100), ikatan emosional yang terbentuk dalam masyarakat dengan budaya politik subjektif ini sangat kuat sehingga perasaan individu menjadi dominan dalam menilai sistem politik yang ada. Terpeliharanya budaya politik subjektif ini berimplikasi pada sikap kemelayuan kaum dan suku yang fanatik sehingga dapat digunakan untuk kepentingan politik praktis.

\section{B. METODE PENELITIAN}

$\mathrm{P}$ enelitian ini menggunakan pendeka tan kualitatif dengan teknik deskriptif. Data dalam penelitian ini dikumpulkan dengan menggunakan kaedah wawancara mendalam yang dilakukan kepada sejumlah informan yang sengaja dipilih dengan menggunakan teknik purposif sampling. Adapun informan yang diwawancarai memiliki latar belakang penghulu adat Melayu, anggota Komisi Pemilihan Umum
Provinsi, politisi, birokrasi, dan akademisi. Data primer diolah dengan mengklasifikasi bagian-bagian wawancara yang relevan dengan masalah yang dikaji dan dianalisis dengan memahami dialektika data primer, data sekunder dan teori yang ada. Untuk mendapatkan data yang dicari, maka penelitian ini mengumpulkan data di Kota Pekanbaru dan Kabupaten Kampar sehingga tergambarkan bagaimana politik kekuasaan penghulu adat dalam penyelenggaraan demokrasi lokal di Riau.

\section{HASIL DAN PEMBAHASAN}

$\mathrm{H}$ ampir semua masyarakat adat di nusantara memiliki adat istiadat yang dikawal dan dikendalikan oleh penghulu adatnya. Penghulu adat ini menjadi tokoh panutan yang diikuti oleh masyarakatnya. Apalagi penghulu adat ini memiliki otoritas tradisional yang memberi kewenangan bagi mereka untuk memberi kan penghargaan dan hukuman kepada masyarakat dalam sukunya. Otoritas tradi sional ini dilegitimasi oleh masyarakat yang hari ini masih dapat ditemukan di berbagai daerah di Indonesia. Salah satunya adalah masyarakat Melayu Riau yang adat budayanya masih ditemukan dalam penye lenggaraan pemerintahan daerah. Misal nya, aturan berpakaian bagi pegawai negeri sipil di Pemerintah Daerah Provinsi Riau, yaitu setiap hari Kamis atau Jumat mereka diwajibkan untuk menggunakan baju teluk belanga (cekak musang) untuk Pria dan baju kurung cekak musang untuk Wanita. Begitu juga dengan pemakaian huruf Arab Melayu di plang nama di setiap jalan di Kota Pekanbaru dan daerah Riau lainnya. Tentu praktik pelestarian adat dan budaya seperti ini juga sebagai bentuk pencarian identitas diri masyarakat Melayu, terutama dalam aspek politik dan pemerintahan.

\section{Sejarah Kebudayaan Melayu Riau}

Provinsi Riau adalah daerah hamparan dengan luas daratan mencapai $89.150 \mathrm{~km}^{2}$ yang kaya dengan hasil alam seperti minyak bumi. Selain itu, hamparan daratan Provinsi Riau yang luas ini, hampir sebagiannya

DOI: 10.25077/jantro.v20.n1.p57-69.2018

JANTRO ISSN: 2355-5963 (Online)

under Lisensi Creative Commons Atribusi-BerbagiSerupa 4.0 Internasional

$60 \mid \mathrm{P}$ a g e 
sudah ditanami dengan Kelapa Sawit. Bahkan sektor kelapa sawit Riau ini menyumbang devisa yang cukup besar bagi Indonesia. Sejak dilaksanakannya otonomi daerah, perkembangan ekonomi daerah Riau terus membaik. Dengan jumlah pendu duk yang mencapai 6,5 juta orang pada tahun 2016, pertumbuhan ekonomi Riau terus membaik. Tercatat dari data Biro Pusat Statistik Riau pertumbuhan ekonomi Riau tahun 2016 mencapai 2,23 persen naik dibandingkan tahun 2015 yang hanya mencapai 0,22 persen. Dengan angka pertumbuhan ekonomi yang baik ini tentu mengundang investasi dan migrasi penduduk ke Daerah Riau.

Merujuk sejarah Riau, daerah ini mulanya adalah daerah kerajaan Melayu yang terpencar-pencar meliputi Kerajaan Indragiri (1658-1838), Kerajaan Siak Sri Indrapura (1723-1858), Kerajaan Pelalawan (1530-1879), Kerajaan Riau-Lingga (18241913), Kerajaan Tambusai, Kerajaan Rantau Binuang Sakti, Kerajaan Rambah, Kerajaan Kampar dan Kerajaan Kandis. Gabungan dari beberapa wilayah kerajaan inilah yang saat ini dikenal dengan Daerah Riau. Memang setelah Indonesia Merdeka, Daerah Riau ini masih menjadi bagian dari Provinsi Sumatera Tengah hingga tahun 1958. Namun, sejak diterbitkannya UU No.61 tahun 1958, maka Provinsi Sumatera
Tengah dipecah menjadi tiga daerah otonomi baru, yaitu Provinsi Riau, Provinsi Sumatera Barat dan Provinsi Jambi. Bahkan pasca jatuhnya kekuasaan Orde Baru, beberapa daerah di Indonesia mengalami pemekaran menjadi daerah otonomi, termasuk Provinsi Riau. Berdasarkan UU No.25 tahun 2002, 5 kabupaten dan kota yang sebelumnya menjadi bagian dari daerah otonom di Provinsi Riau, yaitu Kota Batam, Kota Tanjung Pinang, Kabupaten Kepulauan Riau, Kabupaten Karimun dan Kabupaten Natuna membentuk provinsi baru, yang dikenal dengan Provinsi Kepulauan Riau.

Sesuai dengan dokumen perencanaan pembangunan daerah Provinsi Riau tahun 2014-2019 dinyatakan misi pembangunan yang ke-6, yaitu pembangunan masyarakat yang berbudaya Melayu, beriman dan bertaqwa. Konteks pembangunan masya rakat yang berbudaya Melayu ini menjadi kebijakan pemerintah provinsi untuk menegaskan politik identitasnya untuk memperkuat nilai-nilai kemelayuan yang mulai tergerus. Politik identitas ini terkait dengan kedekatan emosional dan ikatan psikologis yang dibangun bersama dengan anggota kelompok yang lain karena adanya faktor kesamaan ras, bahasa, agama, budaya, kedaerahan dan sebagainya (Joireman, 2003:1-5).

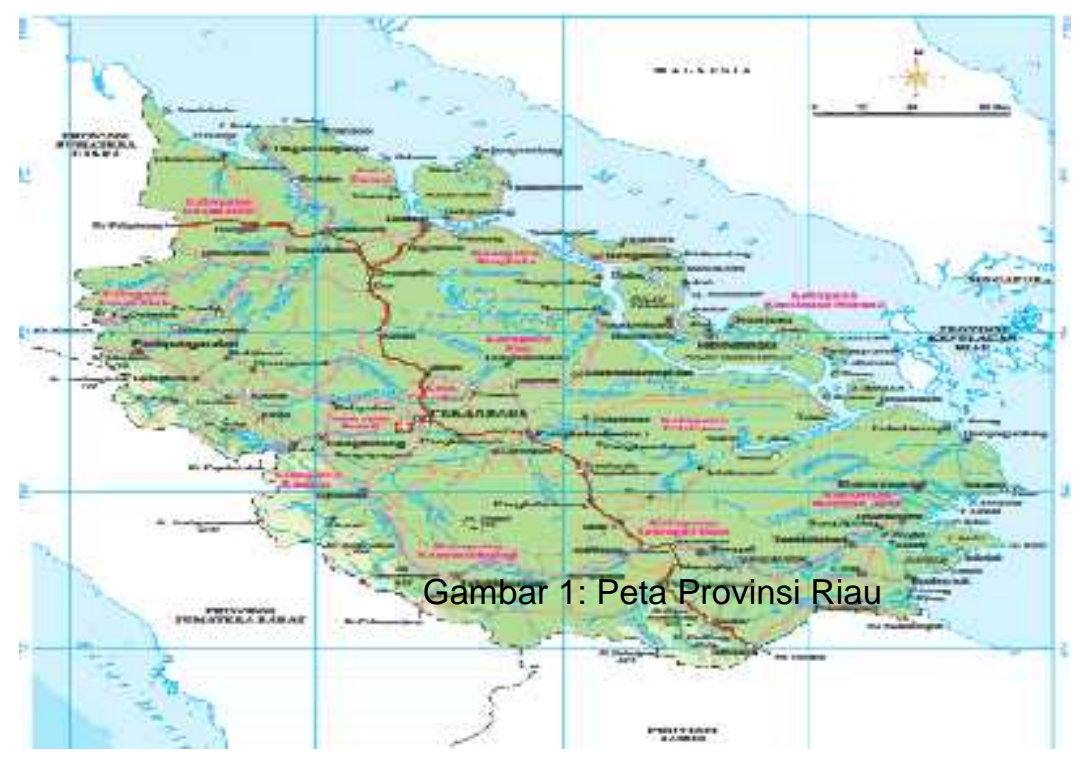

DOI: 10.25077/jantro.v20.n1.p57-69.2018

JANTRO ISSN: 2355-5963 (Online)

under Lisensi Creative Commons Atribusi-BerbagiSerupa 4.0 Internasional 
Walaupun masyarakat Melayu Riau berusaha membangun identitas kemelayuan nya dan menjadikan kemelayuan tersebut berdasarkan budaya, bahasa dan agama sebagai pembeda dengan kelompok masyarakat pendatang, namun identitas tersebut juga mengalami perdebatan. Misalnya, bagi masyarakat di pesisir timur Pulau Sumatra, Melayu pesisir yang meliputi Dumai, Rokan Hilir, Bengkalis, Kepulauan Meranti, sebagian Inderagiri Hilir, Sebagian Siak Sri Indrapura dan sebagaian Pelalawan. Sementara, Melayu daratan dikenal mereka yang berasal dari daerah Pekanbaru, Kampar, Rokan Hulu dan Kuantan Singingi, dan sebagian Indragiri Hulu dianggap berbeda dengan Melayu pesisir. Kecenderung cara pandang yang dikotomi ini menyebabkan politik identitas etnis Melayu Riau menjadi tidak kuat. Fenomena dikotomi cara memandang Melayu ini juga menyebabkan munculnya keinginan sebagian besar elite di daerah pesisir Riau untuk memekarkan kembali Provinsi Riau menjadi Provinsi Riau Pesisir. ${ }^{4}$

Dikotomi cara pandang identitas kemelayuan ini juga menjadi dasar politik sehingga Provinsi Kepulauan Riau terbentuk pada tahun 2002. Bermula dari keterting galan yang dirasakan dari masyarakat Melayu di Riau daratan segi pembangunan bahkan kebudayaan Melayu itu sendiri sejak berpindahnya ibukota Provinsi Riau dari Tanjung Pinang ke Pekanbaru tahun 1959. Padahal Tanjung Pinang pernah menjadi pusat kebudayaan, pusat perdagangan di Selat Melaka dan sejarah Melayu pada masa abad pertengahan. Realita ini mendorong keinginan masyarakat melayu di daerah kepulauan untuk memekarkan daerahnya. Apalagi UU No.22 tahun 1999 tentang pemerintahan daerah memberi ruang untuk pembentukan daerah otonomi baru di Indonesia. Walaupun begitu upaya pemekaran Provinsi Kepulauan Riau ini tidaklah berjalan mudah karena mendapat penolakan dari sebagian besar anggota DPRD Provinsi Riau. Dalam sidang pengambilan keputusan pada tanggal 9 Juni

\footnotetext{
${ }^{4}$ Wawancara dengan Dr. M. Rawa El Amady, Pengamat sosial dan budaya Melayu Riau di Pekanbaru tanggal 7 September 2017.
}

DOI: 10.25077/jantro.v20.n1.p57-69.2018

JANTRO ISSN: 2355-5963 (Online)

under Lisensi Creative Commons Atribusi-BerbagiSerupa 4.0 Internasional
2000 dalam sidang Paripurna DPRD Provinsi Riau berakhir dengan pemungutan suara dengan hasil 21 orang anggota DPRD mendukung pembentukan Provinsi Kepulauan Riau dan 33 orang anggota DPRD menolaknya. Dinamika politik dan lobbying tingkat atas akhirnya membuahkan hasil, maka pada tanggal 24 September 2002 berdasarkan UU No.25 tahun 2002 Provinsi Kepulauan Riau resmi terbentuk (Alhajj, 2012).

Watson (1997) menjelaskan adanya kecenderungan cara pandang elite di Riau yang melihat masyarakat (Melayu) dari perspektif daratan dan kepulauan. Cara pandang seperti ini jelas berdampak pada pembentukan identitas politik yang berpe ngaruh pada perkembangan daerah Melayu Riau. Menurut sejarahnya, Kerajaan Melayu Riau ini menjadi bagian Kerajaan Melaka yang menjadi kerajaan besar di Asia Tenggara (1400-1511 M) yang juga sebagai perdagangan dan perkembangan sosial, budaya dan politik di Selat Malaka. Sejak datangnya Bangsa Portugis sekita abad ke15, maka terjadi konflik dan peperangan dengan kerajaan Melaka termasuk Bangsa Melayu di Pulau Bintan di bawah komando Sultan Mahmud Syah I. Mulai saat itulah Kerajaan Melayu Riau mewarisi kekuasaan kerajaan Melaka di daerah Riau yang mencakup Indragiri, Siak Gasip, Lingga, Kampar dan Rokan. Karenanya tidak mengherankan jika ada pandangan pusat kebudayaan melayu itu ada di kepulauan Riau.

Walaupun sekarang ini kerajaan Melayu Riau tidak ada lagi karena sudah bergabung dengan Republik Indonesia, namun kebudayaan Melayu Riau masih dapat ditemukan. Untuk tetap melestarikan adat dan budaya Melayu ini, maka dibentuk Lembaga Adat Melayu Riau (LAM Riau) pada 6 Juni 1970. Tujuan pembentukan lembaga ini adalah (1) Pelestarian (perlindungan, pengembangan, dan pemanfaatan) nilai-nilai adat dan nilai-nilai sosial budaya, sebagai landasan memperkuat dan memperkokoh jatidiri masyarakat Melayu; (2) Mewujudkan masyarakat adat berbudaya Melayu, maju, adil, dan sejahtera dalam tatanan 
masyarakat madani dalam Negara Kesatuan Republik Indonesia; (3) Memelihara, dan membina hak-hak masyarakat Adat Melayu Riau untuk meningkatkan kesejahteraan lahiriah dan batiniah masyarakat Melayu Riau. Pembentukan LAM ini diprakarsai oleh banyak tokoh seperti dari kalangan pemerintah daerah, budayawan, seniman, kalangan perguruan tinggi dan orang patutpatut yang berasal dari lingkungan orang kekuasaan tradisional Melayu Riau. Jadi, dalam arti yang sesungguhnya, LAM Riau menjaga kelestarian adat Melayu yang semakin terancam eksistensinya karena semakin terbukanya peradaban dunia Melayu (Anon, 2017).

Namun yang jadi persoalan, bagaimanakah hubungan antara otonomi daerah yang dilaksanakan pasca jatuhnya rezim Orde Baru dengan menguatnya identitas kemelayuan Riau? Dalam konteks sosial dan budaya Melayu, apakah LAM Riau juga memiliki pengaruh politik dalam rangka menguatkan identitas kemelayuan tersebut? Pertanyaan berikutnya, apakah dalam konteks pelaksanaan pemilihan kepala daerah, penghulu adat Melayu juga memiliki pengaruh dalam memobilisasi dukungan masyarakat Melayu kepada calon kepala daerah tertentu? Pertanyaan ini tentu sangat berkaitan dengan dinamika politik identitas yang menjadi paradoks dalam praktik demokrasi dalam masyarakat yang majemuk.

\section{Otonomi Daerah dan Politik Identitas Etnis Melayu Riau}

Hal menarik dari pelaksanaan otonomi daerah pasca runtuhnya rezim Orde Baru adalah semakin menguatnya identitas kedaerahan. Bahkan otonomi dimaknai sebagai hak etnis asli daerah tersebut sehingga mengabaikan hak etnis lain sebagai pendatang. Misalnya, semangat kedaerahan yang berlebihan di daerah memunculkan politik identitas. Hal ini yang pernah dilakukan masyarakat Melayu Riau ketika awal reformasi menuntut pemerintah pusat agar lebih memperhatikan pem bangunan di Riau apalgi dengan kekayaan alam yang dimiliki daerah ini, namun tidak dapat dinikmati oleh masyarakatnya. Akibat fenomena politik ini muncul tiga tuntutan yang dipeloporo tokoh-tokoh Melayu Riau seperti Tabrani Rab, Al Azhar dan sebagainya untuk mendesak pemerintah pusat mengabulkan otonomi yang seluasluasnya, pembentukan federalisme atau Riau Merdeka. Bahkan wacana untuk "Gerakan Riau Merdeka" cukup mengemuka dalam tuntutan tersebut sehingga menimbulkan gesekan dengan aparat keamanan di daerah ini (Juniarto, 2005; Albintani, 2001).

Dengan terbitnya UU No. 22/1999 sebagai dasar pelaksanaan otonomi daerah yang seluas-luasnya di Indonesia masyarakat semakin memperkuat identitas politik masing-masing. Berbagai gerakan politik lokal muncul hampir di setiap daerah di Indonesia. Tidak terkecuali Riau bahkan isu putera daerah menjadi isu yang sering dimunculkan, terutama dalam pembuatan kebijakan oleh pemerintah daerah. Umum nya isu putera daerah ini dikaitkan dengan kebijakan prioritas atau kebijakan yang bersifat afirmatif yang diambil oleh pemerintah daerah agar memberi tempat dan ruang kepada etnis asli ketimbang etnis pendatang dalam aktifitas ekonomi, politik, pemerintahan dan sosial budaya (Agustino, 2013). Karenanya tidak mengherankan wacana tentang putera daerah juga bagian penting dari politik identitas yang dilaksanakan di Indonesia, termasuk di Provinsi Riau.

Menguatnya identitas kemelayuan di Provinsi Riau awal Orde Reformasi juga bentuk perlawanan terhadap dominasi pemerintah pusat yang selama rezim Orde Baru berkuasa telah memingirkan eksistensi masyarakat Melayu. Apalagi dengan kondisi kekayaan sumber daya alam provinsi Riau yang melimpah mengharuskan pemerintah pusat memberi perhatian khusus kepada daerah ini. Ini sejalan dengan apa yang dijelaskan Derk (1997:700) bahwa "identity work can be triggered by an awareness of being economically slighted." Karenanya dapat dikatakan bahwa faktor kekayaan ekonomi Riau yang tidak dapat dinikmati menjadi pemicu munculnya identitas masyarakat Riau tersebut. Karenanya ketika otonomi daerah yang seluas-luasnya dibuka, maka yang menguat adalah politik identitas masyarakat Melayu Riau untuk 
mengambil peran yang besar di daerahnya sendiri.

Membangun semangat kemelayuan dalam wacana politik di Riau adalah bagian dari upaya elite memperkuat kedudukan etnis Melayu di tengah banjir pendatang ke daerah ini. Apalagi menjelang pelaksanaan Pemilihan kepala daerah (Pilkada), maka salah satu strategi pemenangan yang dilakukan oleh calon kepala daerah adalah bagaimana menggabungkan dukungan masyarakat Melayu yang ada di Riau daratan dan Riau pesisir dalam Pilkada tersebut. Caranya adalah dengan melibat kan tokoh-tokoh dari kedua daerah tersebut untuk berpasangan sebagai calon gubernur dan wakil gubernur. Politik perwakilan daerah seperti ini terbukti berjalan efektif, khususnya dalam pemilihan gubernur Riau tahun 2013 yang memenangkan Annas Maamun yang mewakili etnis Melayu Pesisir, yaitu Rokan Hilir dan Arsyadjuliandi Rachman yang mewakili masyarakat Melayu daratan, yaitu Kampar. ${ }^{5}$

Pemekaran daerah yang berlangsung di Riau, terutama di masa-masa awal kejatuhan rezim Orde Baru membawa implikasi pada munculnya semangat ke daerahan di masing-masing daerah. Memang pemekaran daerah ini bertujuan untuk meningkatkan pelayanan ke masyarakat dan pemerataan pembangunan. Namun di sisi lain, otonomi daerah juga memunculkan semangat kedaerah yang berlebihan. Beberapa daerah di Provinsi Riau mengalami pemekaran seperti Kabupaten Siak, Kabupaten Rokan Hilir dan Kabupaten Kepulauan Meranti dimekarkan dari Kabupaten Bengkalis, Kabupaten Pelalawan dan Kabupaten Rokan Hulu dimekarkan dari Kabupaten Kampar serta Kabupaten Kuantan Singingi dimekarkan dari Kabupaten Indragiri Hulu. Semangat pemekaran ini juga melahirkan elite lokal baru yang menempati posisi strategis baik di lembaga pemerintahan, partai politik dan organisasi kemasyarakatan. Bahkan munculnya wacana tentang pendirian Provinsi Riau Pesisir akhir-akhir adalah dampak dari semangat kedaerahan

\footnotetext{
${ }^{5}$ Wawancara dengan Ketua KPU Provinsi Riau, Dr. Nurhamin di Pekanbaru tanggal 8 September 2017.

DOI: 10.25077/jantro.v20.n1.p57-69.2018

JANTRO ISSN: 2355-5963 (Online)
}

under Lisensi Creative Commons Atribusi-BerbagiSerupa 4.0 Internasional berlebihan dari sebagian etnis Melayu di daerah ini. ${ }^{6}$

Menguatnya politik identitas sejak otonomi daerah dilaksanakan berdampak pada asal usul dan solidaritas orang Melayu sebagai sukubangsa yang sudah lama menetap di Provinsi Riau. Dari sisi lain, politik identitas orang Melayu juga dapat menjadi pembeda di antara mereka sehingga muncul Riau daratan dan Riau Pesisir. Namun, jika dilihat realitanya, masyarakat Provinsi Riau yang sangat majemuk dengan sukubangsa ini juga mengakui kebudayaan Melayu sebagai bagian dari kebudayaan mereka. Terbukti bahwa masyarakat yang tinggal di daerah Riau juga merasakan kemelayuannya dari tradisi dan simbol kebudayaan Melayu yang ada di sekitar mereka. "Tradisi dan simbol tersebut menyelimuti berbagai suasana kehidupan masyarakat dan menghasilkan pengakuan dari berbagai sukubangsa dan etnik yang hidup di wilayah provinsi Riau. Simbol-simbol signifikan yang berasal dari kebudayaan Melayu ini kemudian menjadi identitas masyarakat Provinsi Riau" (Suparlan, 2007:650).

Menariknya hanya masyarakat Melayu Riau yang merasakan perbedaan dengan sukubangsa lain yang datang ke daerah Riau. Padahal mereka yang disebut sebagai pendatang juga merasakan identitas kemelayuan tersebut. Karenanya tidak mengherankan muncul istilah bagi mereka yang turut merasakan tradisi dan simbol kemelayuan ini walaupun bukan sebagai orang Melayu "asli" sebagai orang Riau. Keberadaan orang Riau ini juga sangat penting, khususnya dalam rangka mendukung pelaksanaan program pemerintah. Malah dalam konteks pemilihan kepala daerah, eksistensi orang Riau ini menjadi strategis untuk mendukung perpolitikan elite Melayu itu sendiri.

\footnotetext{
${ }^{6}$ Wawancara dengan Dr. M Rawa El Amady, Op.Cit.

${ }^{7}$ Wawancara dengan Sumiyanti anggota DPRD Provinsi Riau dari Partai Golkar tanggal 7 September 2017.
} 


\section{Kekuasaan Penghulu Adat Melayu dan Pengaruhnya Dalam Pilkada Riau}

Di banyak daerah, politik identitas juga dijadikan sarana legitimasi dukungan politik, terutama dalam pemilihan kepala daerah. Umumnya calon kepala daerah mengusung isu-isu lokal seperti etnis lokal yang terpinggirkan hingga hilangnya kewibawaan bangsawan lokal akibatnya sentralisasi kekuasaan pemerintah. Pilihan isu-isu lokal ini masih menarik masyarakat untuk menggali kembali identitas-identitas politik di tengah praktik demokrasi lokal yang semakin terbuka. Bahkan dalam beberapa hal isu-isu lokal ini menjadi dasar pertimbangan bagi pemilih setempat ketika Pilkada dilaksanakan. Beberapa kajian menunjukan kecenderungan ini. Sebut saja Aspinall \& Fealy (2003:6) melihat masih adanya persoalan terkait dengan pelaksanaan desentralisasi yang memun culkan isu putra daerah dan elite lokal untuk mendapatkan sumber daya ekonomi dan posisi di jabatan pemerintahan daerah. "...many regions have witnessed campaigns for local people or putra daerah (literally, 'son of the region') to control local government and secure preferential treatment for their communities in the allocation of economic resources and government posisition."

Isu-isu lokal ini sering digunakan dalam kontestasi Pilkada sehingga mengun tungkan bagi calon kepala daerah yang berasal dari etnis yang sama. Apalagi sejak dilaksanakan pemilihan kepala daerah tahun 2005 semakin nyata pengaruh yang dilakukan oleh elite lokal yang berasal dari etnis dominan. Mereka ikut mempengaruhi dinamika Pilkada tersebut untuk kepenti ngan etnis setempat. Elite lokal yang berpengaruh dalam dinamika politik di Riau memiliki latar belakang yang beragam di antaranya pengurus partai politik, pejabat birokrasi, bekas pejabat birokrasi dan militer, pengusaha, akademisi, budayawan, seniman dan lain sebagainya. Elite lokal ini memainkan pengaruhnya ketika Pilkada berlangsung. Bahkan persaingan di antara mereka yang terlibat langsung dalam Pilkada berlangsung sangat ketat. Akibat persaingan tersebut baik sebagai calon atau

DOI: $10.25077 /$ jantro.v20.n1.p57-69.2018

JANTRO ISSN: 2355-5963 (Online)

under Lisensi Creative Commons Atribusi-BerbagiSerupa 4.0 Internasional sebagai pendukung calon telah melupakan esensi budaya Melayu yang sebenarnya dapat menjadi perekat di antara mereka. Begitu juga dengan keinginan calon kepala daerah yang ingin melibatkan penghulu adat Melayu sebagai tim sukses calon kepala daerah dilakukan karena dianggap memiliki legitimasi tradisional yang dapat mempe ngaruhi komunitas adatnya. Walaupun dalam banyak kasus yang dijumpai seperti dalam etnis Minangkabau dan etnis Melayu Jambi, jarang sekali legitimasi adat tersebut efektif memobilisasi komunitasnya dalam Pilkada (Asrinaldi, 2017).

Begitu juga dengan penghulu adat Melayu Riau jarang sekali menggunakan kekuasaan adat yang dimilikinya untuk kepentingan politik praktis. Memang dalam kasus tertentu ada keterlibatan penghulu adat dalam Pilkada, tapi keterlibatan itu tidak mewakili LAM-tempat mereka beraktifitas. Karena dalam Anggaran Dasar (AD) dan Anggaran Rumah Tangga (ART) LAM ini memang tidak memiliki fungsi politik sebagaimana yang dikenal dalam partai politik. ${ }^{8}$ Walaupun begitu, karena adanya keberagaman latar belakang profesi pengurus LAM Riau ini, jelas berdampak pada afiliasi politik mereka. Karenanya tidak mengherankan, masyarakat mengaitkan kedudukannya pengurus LAM ini dengan kegiatan politik praktis seperti Pilkada.

Kekuasaan penghulu adat masyarakat Melayu Riau hanya sebatas dalam komunitasnya. Kedaulatan kekuasaan penghulu adat tidaklah melintasi sempadan wilayah hukum adat yang lain. Karenanya penghulu adat hanya berdaulat dalam kaum dan suku yang ada di wilayah adatnya. Hal ini bisa terjadi karena legitimasi kekuasaan penghulu adat Melayu hanya diberi oleh kaumnya. Berbeda halnya dengan Lem baga Adat Melayu Riau yang tidak memiliki akar budaya di dalam kaumnya. Sebab yang menjadi pengurus LAM Riau ini kebanyakan adalah mereka yang berlatar belakang mantan pejabat pemerintahan, budayawan dan seniman Melayu. Akibat nya legitimasi yang mereka miliki hanya sebatas dalam kepengurusan LAM Riau

\footnotetext{
${ }^{8}$ Wawancara dengan Abdul Hamid, anggota KPUD Provinsi Riau, tanggal 8 September 2017.
} 
saja dan tidak menjangkau komunitas adat yang ada di daerah di Riau. ${ }^{9}$

Walaupun LAM Riau tidak berpolitik, namun perannya dalam Pilkada juga dapat dilihat dari himbauannya terkait dengan kepala daerah adalah orang Melayu. Memang himbauan ini tidaklah mengikat karena faktanya ada juga calon kepala daerah yang juga berasal dari sukubangsa lain. Namun, hal ini tidaklah menjadi persoalan bagi masyarakat Melayu Riau. Begitu juga dengan kegiatan seremoni lainnya yang dilakukan oleh LAM Riau, yaitu memberi "Tepung Tawar" kepada calon kepala daerah agar pelaksanaan Pilkada menjadi lebih berkah, harmonis dan berjalan dengan lancar. ${ }^{10}$ Dalam konsep adat Melayu, proses "Tepung Tawar" ini adalah bentuk rasa syukur masyarakat kepada Allah SWT yang telah memberkati kehidupan mereka dengan segala aktifitas yang dijalani sehari-hari. Biasanya prosesi Tepung Tawar ini terdapat dalam adat pernikahan masyarakat Melayu (Ediruslan, 2000). Namun, karena semakin berkem bangnya budaya Melayu ini sehingga penggunaan tepung tawar ini tidak hanya dalam konteks perkawinan, tapi juga acaraacara resmi seperti launching Pilkada.

Walaupun tidak memiliki pengaruh politik yang signifikan, namun kehadiran LAM Riau di tengah kehidupan masyarakat Melayu sangat penting. Apalagi, sesuai dengan tujuan pembentukannya, LAM menjaga dan melestarikan budaya Melayu di Riau yang menjadi identitas masyarakat Riau yang mejemuk. Memang, dari satu sisi, LAM Riau memiliki kepentingan terhadap kekuasaan, terutama mencari dukungan kebijakan penguasa untuk dapat menjaga dan melestarikan budaya Melayu tersebut. Oleh karena itu, untuk mendekatkan hubungan antara LAM Riau dengan penguasa dalam hal ini kepala daerah, maka LAM Riau juga memberi gelar adat kepada gubernur. Misalnya, memberi gelar adat Datuk Seri Setia Amanah kepada Gubernur Riau Arsjadjuliandi Rachman karena dianggap berjasa dalam meningkatkan harkat, martabat, dan pelestarian adat budaya

\footnotetext{
${ }^{9}$ Wawancara dengan Dr. Rawa El Amady, Op.Cit.

${ }^{10}$ Wawancara dengan Abdul Hamid, Op.Cit.

DOI: 10.25077/jantro.v20.n1.p57-69.2018

JANTRO ISSN: 2355-5963 (Online)

under Lisensi Creative Commons Atribusi-BerbagiSerupa 4.0 Internasional
}

Melayu Riau sebagaimana yang dimaksud dalam Pasal 29 Ayat 1 Anggaran Rumah Tangga Lembaga Adat Melayu Riau. Dengan cara ini, secara tidak langsung LAM Riau membangun relasi kekuasaan dengan gubernur. Begitu juga dengan gubernur secara tidak langsung, mendapatkan legitimasi kultural dari LAM Riau untuk menyelenggarakan kekuasaan politik yang ada di tangannya.

Memang dalam pelaksanaan Pemilihan Gubernur Riau pada 26 Juni 2018, sudah beredar poster dan baliho calon gubernur di daerah-daerah di Provinsi Riau. Sama dengan pemilihan gubernur Riau sebelum nya tahun 2013 , banyak calon yang muncul dan umumnya mereka adalah bekas bupati dan bupati yang sedang menjabat. Mereka bertarung dengan membawa kebesaran nama masing-masing sebagai tokoh masyarakat Melayu di Provinsi Riau. Pada pemilihan gubernur tahun 2013 tersebut terdapat 5 pasang calon gubernur dan wakil gubernur yang maju dalam pemilihan tersebut, yaitu Herman Abdullah-Agus Widayat, Annas Maamun-Arsyadjuliandi Rachman, Lukman Edy-Suryadi Khusaini, Achmad-Masrul Kasmy, dan Jon ErizalMambang Mit. Dari pasangan calon gubernur tersebut terlihat representasi orang Melayu daratan dan Melayu pesisir seperti Herman Abdullah mantan walikota Pekanbaru yang mewakili Melayu daratan berpasangan dengan Agus Widayat yang menjabat sebagai wakil walikota Dumai mewakili Melayu pesisir. Begitu juga dengan Anaas Maamun sebagai bupati Rokan Hilir mewakili Melayu pesisir dan Arsyadjuliandi Rachman anggota DPR-RI mewakili Melayu daratan. Achmad yang juga bupati Rokan Hulu mewakili Melayu daratan berpasangan dengan Masrul Kasmy yang juga wakil bupati Kepulauan Meranti mewakili Melayu Pesisir.

Menariknya calon gubernur tersebut berusaha memainkan sentimen kedaerahan masing-masing untuk mendapatkan suara berdasarkan ikatan kedaerahan asal calon. Namun, isu tentang kemelayuan jarang muncul sebagai cara menarik dukungan masyarakat Melayu. Karena dari sebaran komposisi etnis yang ada di Provinsi Riau 
tidak berbeda jauh jumlahnya seperti etnis Melayu mencapai 33,02 persen, Jawa 29,03 persen, Batak 12,08 persen, Minangkabau sebanyak 12,22 persen. Sementara suku lain seperti Banjar, Bugis, Tiong Hoa dan sebagainya tidak sampai 10 persen. Tentu dengan memainkan isu sentimen keme layuan akan merugikan calon kepala daerah yang bertanding dalam Pilkada tersebut karena komposisi masyarakat Riau yang jumlahnya hampir merata.

Jadi dapat ditegaskan bahwa kebera daan penghulu adat Melayu juga tidak begitu mempengaruhi perilaku memilih masyarakat Melayu, khususnya pemilihan kepala daerah. Keterlibatan penghulu adat dalam aktifitas politik dan pemerintahan hanya dalam rangka bagaimana adat Melayu Riau digunakan dalam penyeleng garaan pemerintahan. Tentunya ini tidak lepas dari kebijakan yang dibuat oleh pemerintah daerah, melalui kepala daerahnya, sehingga adat dan budaya Melayu Riau tidak hilang dalam kehidupan masyarakat. Bahkan bagi sebagian peng hulu adat Melayu Riau, keterlibatan penghulunya dalam aktifitas politik akan menurunkan marwah institusi adat. Idealnya institusi adat ini menjadi penjaga nilai-nilai adat dan budaya Melayu Riau.

\section{KESIMPULAN}

$\mathrm{D}$ atas sudah dijelaskan bahwa masyarakat Riau memiliki cara pandang terhadap adat dan budaya Melayu. Umumnya mereka membagi Mela yu pada dua geografi, yaitu masyarakat Melayu yang berada di daratan yang mengamalkan adat dan budaya yang bersinggungan dengan adat budaya Minangkabau di Sumatera Barat. Semen tara yang lain, adat Melayu pesisir yang bersinggungan dengan kebudayaan Melayu yang dulu pernah berpusat di Kepulauan Riau. Walaupun ada dua aliran kebudayaan yang bisa diidentifikasi, namun di antara keduanya ini saling melengkapi dan saling bersebati, terutama di daerah-daerah yang beratasan geografi seperti di daerah Pelalawan, Siak, dan Rokan Hulu. Sifat kebudayaan Melayu yang juga terbuka menyebabkan terjadinya asimilasi kebuda yaan dengan kebudayaan lain yang masuk ke dalam aktifitas adat dan tradisi Melayu. Ini dapat dilihat dari berkembangnya kebudayaan Melayu yang dipengaruhi oleh budaya Jawa, budaya Bugis, budaya Banjar dan sebagainya. Karenanya tidak menghe rankan jumlah masyarakat pendatang ke daerah Riau cukup besar dan berdampak pada komposisi penduduknya. Konsekuen sinya menyebabkan munculnya istilah yang sering disebut sebagai orang Riau ketimbang orang Melayu Riau.

Eksistensi orang Melayu Riau yang terbagi pada dua geografi Melayu daratan dan Melayu pesisir ditambah dengan keberadaan orang Riau dengan bebagai etnis berdampak pada konstelasi politik dan demokrasi lokal yang ada. Hal ini bisa dilihat dari pelaksanaan otonomi daerah yang memunculkan semangat kemelayuan dengan memunculkan isu putera daerah di awal pelaksanaan otonomi daerah. Begitu juga dengan pemilihan gubernur munculnya keinginan untuk memadukan dua geografi ini, yaitu calon yang berasal dari Melayu pesisir dengan Melayu daratan. Dari sisi lain, keterwakilan orang Riau yang jumlahnya juga signifikan di Provinsi Riau juga harus dipertimbangkan sebagai bentuk tambahan dukungan dalam Pilkada tersebut.

Posisi penghulu adat Melayu juga perlu menjadi perhatian karena mereka adalah individu yang ikut menjaga dan melestarikan kebudayan Melayu. Bahkan penghulu adat Melayu ini secara tidak langsung juga menjadi pemimpin bagi masyarakat Melayu baik di pesisir maupun di daratan. Walaupun kepemimpinan ini bersifat tradisional, masyarakat Melayu memberi legitimasi kuat kepada mereka sehingga cakupan kekuasaan penghulu ini tidak hanya dalam konteks adat dan budaya Melayu saja. Dalam beberapa hal, penghulu adat Melayu ini juga memiliki legitimasi politik dalam kaum dan sukunya. Faktanya kekuasaan politik penghulu adat Melayu ini jarang digunakan mengarahkan anggota kaum dan sukunya untuk terlibat dalam politik praktis seperti Pilkada. Begitu juga pembentukan LAM Riau bertujuan untuk menjaga dan melestarikan kebuda 
yaan Melayu agar tetap hidup dan berkembang dalam masyarakat Riau.

Dalam aktifitas politik praktis, kebera daan penghulu adat Melayu Riau tidak begitu siginifikan. Umumnya mereka tidak pernah membicarakan aktifitas politik kepada kaum dan sukunya secara serius. Begitu juga dalam konteks pemilihan kepala daerah, kalaupun ada pembicaraan terkait calon pemimpin mereka ke depan, biasanya dilakukan sambil lalu saja. Sementara di LAM Riau, penghulu adatnya juga tidak terlibat politik praktis karena memang tidak sesuai dengan tujuan lembaga ini dibentuk. Memang tidak sedikit calon kepala daerah yang mengunjungi LAM Riau, tapi dalam konteks sosialisasi diri kepada pengurus LAM Riau memohon dukungan moril dari tokoh adat Melayu yang berhimpun dalam lembaga ini secara personal. Keberadaan penghulu adat Melayu justru mewakili institusi dalam upayanya membangun relasi dengan kepala daerah untuk melestarikan nilai adat dan budaya Melayu Riau.

\section{E. UCAPAN TERIMA KASIH}

A rtikel ini merupakan hasil penelitian ini dibiayai oleh Kementerian Ristek dan Dikti melalui skim Hibah Kompetensi tahun 2017. Peneliti mengucapkan terima kasih kepada semua pihak yang sudah membantu penelitian ini terlaksana sehingga sebagian hasilnya bisa dipublikasikan di jurnal ini.

\section{Daftar Pustaka}

Agustino, Leo (2011). Sisi gelap Otonomi Daerah: Sisi Gelap Desentralisasi di Indonesia Berbanding Era Sentralisasi. Bandung: Widya Padjadjaran.

Albintani, Muchid (2001). Dari Riau Merdeka Sampai Otonomi Nol. Pekanbaru: Unri Press.

Alhajj, Effendy Asmawi (2012). Sejarah Pembentukan Provinsi Kepulauan Riau, 23 Maret 2012, <http://effendyalhajj.blogspot.co.id/2012/03/sejarah-pembentukan-provinsikepulauan.html> diakses 19 September 2017.

Anonim (2017). "Profil Lembaga Adat Melayu Riau", 28 Februari 2017, <https://lamriau.id/profil-lam-riau/> diakses tanggal 16 September 2017.

Aspinall, Edward \& Fealy Greg (2003). Introduction: Decentralisation, Democratisastion adn the Rise of the Local, dalam Edward Aspinall \& Greg Fealy (Eds.), Local Power and Politics in Indonesia: Decentralisation \& democatisation, Singapore: ISEAS, pp. 1-14.

Asrinaldi (2017). Power Network of Penghulu Adat in the Concurent Regional Election in West Sumatera, Jurnal IImu Sosial dan IImu Politik, Vol. 21. No 1, pp. 57-73.

Asrinaldi (2017a). Demokrasi Lokal di Indonesia: Otonomi, Nagari, dan Sosial Budaya di Sumatera Barat. Padang: Erka Publishing.

Derks, W (1997). Malay identity work, In: Bijdragen tot de Taal-, Land- en Volkenkunde, Riau in transition 153 (1997), No: 4, Leiden, 699-716. http://www.kitlv-journals.nl Diakses 7 September 2017.

Effendy, Tenas (2013). Kearifan Pemikiran Melayu, Pekanbaru: Tenas Effendy Foundation.

Gaffar, Afan (1999). Politik Indonesia: Transisi Menuju Demokrasi. Yogyakarta: Pustaka Pelajar.

Hamidy, UU (1993). Beberapa Aspek Sosial dan Budaya di Daerah Riau. Pekanbaru: Unri Pres.

Haba, John (2011). Bukit Tigapuluh: Persepsi Stakeholder dan Masyarakat Melayu Riau. Dalam Herman Hidayat, John Haba \& Robert Siburian (Eds). Politik Ekologi: Pengelolaan Taman Nasional Era Otda, Jakarta: LIPI Pres \& Yayasan Pustaka Obor Indonesia. Pp. 11-41.

Juniarto, Digdo (2005). Riau Dalam Tiga Opsi: Otonomi, Federal atau Merdeka. Pekanbaru: Indonesian Society for Democracy and Peace.

DOI: 10.25077/jantro.v20.n1.p57-69.2018

JANTRO ISSN: 2355-5963 (Online)

under Lisensi Creative Commons Atribusi-BerbagiSerupa 4.0 Internasional

68 | $\mathrm{P}$ a g e 
Marnelly, T. (2018). DINAMIKA SOSIAL BUDAYA MASYARAKAT MELAYU PESISIR (Studi Pengelolaan Madu Sialang di Desa Rawa Mekar Jaya). Jurnal Antropologi: Isu-Isu Sosial Budaya, 19(2), 149-154. doi:https://doi.org/10.25077/jaisb.v19.n2.p149154.2017

Pe Amanriza, Ediruslan (2000). Senarai Upacara Adat Perkawinan Melayu Riau, Pekanbaru: Unri Press.

Pye, Lucyan W (1985). Asian Power and Politics: The Cultural Dimension of Authority. Massachusetts: Harvard University Press.

Suparlan, Parsudi (2007). Melayu dan Non Melayu di Riau: Kemajemukan dan Identitas, dalam Heddy Shri Ahimsa-Putra (Ed.), Masyarakat Melayu dan Budaya Melayu dalam Perubahan, Yogyakarta: Balai Kajian dan Pengembangan Budaya Melayu, pp. 649-657. 